\title{
Epidemiology and Aetiological Diagnosis of Corneal Ulceration in Sana'a City, Yemen
}

\author{
Essam Yahya A Alshamahi ${ }^{1}$, Abeer Abdualkareem Al Nahary ${ }^{2}$, Hassan A Al Shamahy ${ }^{2 *}$, Rahma Taher Farea \\ AL Magrami ${ }^{2}$ and Mohammed Abdullah Alhowthi ${ }^{1}$
}

${ }^{1}$ Department of Opthalmology, Sana'a University, Republic of Yemen

${ }^{2}$ Department of Medical Microbiology and Clinical Immunology, Sana'a University, Republic of Yemen

*Corresponding author: Prof Hassan Al-Shamahy, Department of Opthalmology,

Sana'a University, Republic of Yemen.

Received Date: November 27, 2019

Published Date: December 16, 2019

\section{Abstract}

Background: Corneal ulcer is an inflammatory or more serious condition of the cornea involving a disorder of the epithelial layer with involvement of the corneal stroma. It is a common condition in humans, especially in the tropics and agricultural communities.

Objectives: To identify epidemiological characteristics and risk factors leading to corneal ulceration in Sana'a, Yemen, and to identify specific pathogenic organisms responsible for infection.

Methods: All patients with suspected infectious central corneal ulceration presenting to the ophthalmic clinics in the main hospitals of Sana'a city, Yemen from 1 January to 31July 2017 were evaluated. The clinical samples culturing, and diagnosis were done at National Center of Public Health laboratories Sana'a (NCPHL). Social, demographic data and information relating to risk factors were recorded, all patients were screened, and corneal scrapes and cultures were performed.

Results: In 7-month period 108 patients with central corneal ulceration were evaluated. The male to female ratio was 3.5:1, and the patient ranged in age from 1 to 80 years. The most common risk factor was trauma in $26.9 \%$ of patients, followed by previous eye surgery and previous eye diseases of 5.6\%. Other risk factors such as dryness and trauma, facial palsy, previous viral infections, and dryness were less common. Agents responsible for the trauma were mainly vegetable matter (36.4\%) followed by blunt trauma (15.2\%), while chemical injury was only $6.1 \%$ of total trauma. In other hand $42.4 \%$ of patients were unknown of the agents responsible for the trauma. Cornea laboratory diagnoses were positive in 77 patients $(71.3 \%$ ), of those individuals with positive cultures $42.6 \%$ had pure bacterial infections, $6.5 \%$ had pure viral infections, and $5.6 \%$ had pure fungal infections. The most common bacterial pathogen isolated was Staphylococcus aurous ( $41.3 \%$ of all positive bacterial cultures), followed by Streptococcus viridians (6.3\%), and Staphylococcus epidermidis (6.3\%). The most common fungal pathogen isolated was Candida albicans (41.2\% of all positive fungal cultures), followed by filamentous fungi (23.6\%).

Conclusion: These findings have important public health implications for the treatment and prevention of corneal ulceration in developing countries such as Yemen. Such comprehensive surveys are necessary to assess the specific epidemiological characteristics of corneal ulceration that are unique to each region and population.

Keywords: Epidemiology; Aetiological diagnosis; Corneal ulceration; Yemen

\section{Introduction}

The fourth cause of blindness globally (5.1\%), corneal blindness is one of the main causes of vision loss after cataracts, glaucoma and age-related macular degeneration (AMD). Trachoma is responsible for about 4.9 million blind people, mainly due to corneal and vascular scarring. Ophthalmic trauma and corneal ulcers are important causes of corneal blindness. It is often reported but estimated between 1.5 to 2.0 million new cases of single blindness each year. Among the causes of childhood blindness (about 1.5 million cases in the world and 5 million children with visual impairment) the emergence of xerophthalmia $(350,000$ cases per year), neonatal conjunctivitis, and rare eye infections such as herpes and keratoconjunctivitis [1,2]. Corneal ulcer is an inflammatory or more serious condition of the cornea involving a disorder of the epithelial layer with involvement of the corneal stroma. It is a common condition in humans, especially in the tropics and agricultural communities. In ophthalmology, corneal ulcers usually indicate an infectious cause while corneal erosion refers to physical erosion [2]. It is caused by trauma, especially 
due to vegetables, as well as chemical injury, contact lenses and infections. Other eye conditions can cause corneal ulcers, such as as entropion, distichiasis, corneal dystrophy, and keratoconjunctivitis sicca (dry eye) [1].

Central corneal ulceration is a major cause of monocular blindness in developing countries. Surveys conducted in Africa and Asia confirmed this finding, [1-6] and a recent report on causes of blindness worldwide that consistently lists corneal scars second only to cataracts as the leading causes of blindness and visual impairment in many developing countries in Asia, Africa, and the Middle East including Yemen $[1,2]$.

Given the importance of ulceration as a global cause of monocular vision loss, there are a few surprising studies evaluating pathogenic diseases that threaten populations to corneal infection $[3,4]$. Several researchers have reported the prevalence of bacterial and fungal pathogens isolated from ulcerated corneas, [3-9] but so far there has been no population-based study showing the true incidence of microbial keratitis in a developing country including Yemen.

The epidemiological pattern of corneal ulceration varies greatly from country to country and even from region to region. In order to develop a comprehensive strategy to diagnose, treat, and ultimately to prevention of corneal infections, ulcer-causing pathogens and responsible pathogenic organisms should be identified. Answers to these questions are crucial if a programmed of prevention is to be considered and if appropriate therapeutic measures are to be instituted. The purpose of this study was to evaluate all infectious central corneal ulcers seen in eye clinics in major hospitals in Sana'a city, Yemen over a period of 7 months from 1 January to 31 July 2017. The study documented the antecedent factors predisposing to onset of corneal ulceration and identification of specific organisms responsible for infection.

\section{Materials and Methods}

\section{Patients}

All patients with infectious central corneal ulcers presenting to eye clinics in major hospitals in Sana'a city, Yemen over a period of 7 months from 1 January to 31 July 2017 were included in the study. Consecutive patients were seen after the initial clinical diagnosis of corneal ulceration. Ulceration and loss of corneal epithelium were defined with underlying stromal infiltration and associated restriction, with signs of inflammation with or without hypopyon. A standardized form was filled on each patient documenting social and demographic information as well as clinical information including duration of symptoms, previous treatment, predisposed ocular conditions and associated risk factors.

\section{Clinical procedures}

Each patient was examined in a biological microscope by an ophthalmologist. The size of the epithelial defect was measured after staining with fluoresce with microscope and recorded in millimeters in a standardized shape. In a similar way the size and depth of stromal infiltrate were recorded. A sketch of each ulcer was also painted on the model using frontal and cross-sectional diagrams, and the presence or absence of hypopyon and height measurement in millimeters were recorded. Eye-related conditions such as blepharitis, dacryocystitis, dry eyes, corneal anesthesia, or ocular leprosy were noted. After a detailed eye examination, corneal scraping was performed under sterile conditions on each ulcer by an ophthalmologist using a flame sterile Kimura spatula. Scraping was performed in the operating microscope after instillation of $4 \%$ lignocaine (lidocaine) without preservatives.

The material obtained from the anterior edge scraping and the base of each ulcer was inoculated directly onto blood agar, chocolate agar, dextrose agar (PDA), and in brain heart infusion broth (BHI) without gentamicin sulfate. Material from the corneal scraping was also smeared on three separate glass slides: one for Gram stain, one for Giemsa stain, and the third for microscopic examination as a $\mathrm{KOH}$ wet mount. When $\mathrm{KOH}$ smears were positive for amoebic cysts a further corneal scraping was performed and the material was inoculated onto non-nutrient agar overlaid with Escherichia coli in an attempt to isolate Acanthamoeba spp.

\section{Laboratory procedures}

The clinical samples culturing, and diagnosis were done at National Center of Public Health laboratories Sana'a (NCPHL). All bacterial cultures were incubated aerobically at $37^{\circ} \mathrm{C}$. Cultures on blood agar and chocolate agar were assessed at 24 hours and at 48 hours and then discarded if there was no growth. Inoculated cultures in BHI were examined in a similar manner. Fungal cultures are incubated on the PDA at $27^{\circ} \mathrm{C}$, examined daily, and discard at 1 week if there is no growth. Cultures on non-nutrient agar overlapped with E.coli were examined daily for the presence of Acanthamoeba spp and also discarded in one week if there were no signs of growth.

Microbial cultures were considered positive only if the growth of the organism itself appeared on two or more solid media; or there was a semi-wavy growth at the inoculation site on a solid medium connected to the identification of the organism from morphology and the staining properties of the stained cornea smears by Gram or Giemsa. Cultures for Staphylococcus epidermidis and diphtheroid were considered positive only if there was moderate growth on at least two solid media. Liquid media are found to be easily contaminated so that they cannot be relied upon to accurately identify organisms. Specific identification of bacterial pathogens was based on microscopic morphology, staining properties, and biochemical properties using standard laboratory methods. The fungi were identified by the characteristics of their colonies on PDA and their microscopic appearance in cotton lactophenol blue. Specific clinical diagnosis of HSV was performed by ophthalmologists and optometrists based on the presence of distinct clinical features.

\section{Statistical analysis}

The analysis of the data was performed using SPSS 21.0 for Windows (SPSS Inc., Chicago, IL, USA). The Mann-Whitney U-test was used to determine statistical significance of rate variations. The significance level was set at $\mathrm{p}<0.05$. 


\section{Results}

Table 1: The age and sex distribution of patients of keratitis attending ophthalmic clinics in the main hospital of Sana'a city.

\begin{tabular}{|c|c|c|c|c|c|c|}
\hline \multirow{2}{*}{ Age Group } & \multicolumn{2}{|c|}{ Male $n=84$} & \multicolumn{2}{|c|}{ Female $n=24$} & \multicolumn{2}{|c|}{ Total $n=108$} \\
\hline & No & $\%$ & No & $\%$ & No & $\%$ \\
\hline$<10$ Yrs & 4 & 4.8 & 2 & 8.3 & 6 & 5.6 \\
\hline $10-15$ Yrs & 9 & 10.7 & 5 & 20.8 & 14 & 13 \\
\hline $16-25$ Yrs & 10 & 12 & 3 & 12.5 & 13 & 12 \\
\hline $26-35$ Yrs & 13 & 15.5 & 2 & 8.3 & 15 & 13.9 \\
\hline 36-45 Yrs & 11 & 13.1 & 3 & 12.5 & 14 & 13 \\
\hline 46-55 Yrs & 21 & 25 & 4 & 16.7 & 25 & 23.1 \\
\hline$>56$ Yrs & 16 & 19 & 5 & 20.8 & 21 & 19.4 \\
\hline Total & 84 & 77.8 & 24 & 22.2 & 108 & 100 \\
\hline Mean & \multicolumn{2}{|c|}{ 39.4 Yrs } & \multicolumn{2}{|c|}{ 36.6 Yrs } & \multicolumn{2}{|c|}{ 38.7 Yrs } \\
\hline SD & \multicolumn{2}{|c|}{ 19.5 Yrs } & \multicolumn{2}{|c|}{ 23.3 Yrs } & \multicolumn{2}{|c|}{ 20.4 Yrs } \\
\hline Median & \multicolumn{2}{|c|}{40 Yrs } & \multicolumn{2}{|c|}{38 Yrs } & \multicolumn{2}{|c|}{40 Yrs } \\
\hline Mode & \multicolumn{2}{|c|}{50 Yrs } & \multicolumn{2}{|c|}{50 Yrs } & \multicolumn{2}{|c|}{50 Yrs } \\
\hline Min & \multicolumn{2}{|c|}{1 Yrs } & \multicolumn{2}{|c|}{1 Yrs } & \multicolumn{2}{|c|}{1 Yrs } \\
\hline Max & \multicolumn{2}{|c|}{80 Yrs } & \multicolumn{2}{|c|}{80 Yrs } & \multicolumn{2}{|c|}{80 Yrs } \\
\hline
\end{tabular}

Table 2: The rate of occurrence of risk factors of contracting corneal ulcers in Sana'a city, Yemen.

\begin{tabular}{|c|c|c|}
\hline Risk Factors & Number of Cases & Percentage \\
\hline Previous eye surgery & 6 & 5.6 \\
\hline Trauma & 29 & 26.9 \\
\hline Dryness and trauma & 3 & 2.8 \\
\hline Dryness & 3 & 2.8 \\
\hline Exposure keratitis secondary to \\
facial palsy & 4 & 3.7 \\
\hline Previous viral infection & 4 & 3.7 \\
\hline Previous eye surgery and DM & 1 & 0.9 \\
\hline Post contact lens wearer & 1 & 0.9 \\
\hline Chronic eye allergy & 2 & 1.9 \\
\hline Systemic diseases & 2 & 1.9 \\
\hline Previous eye diseases & 6 & 5.6 \\
\hline Unknown & 43 & 39.8 \\
\hline None & 4 & 100 \\
\hline Total & 108 & 3.7 \\
\hline
\end{tabular}

The study results are presented in 7 tables (1-7 tables. In 7-month period 108 patients with central corneal ulceration were evaluated. The male to female ratio was 3.5:1, and the patient ranged in age from 1 to 80 years (Table 1). The most common risk factor was trauma in $26.9 \%$ of patients, followed by previous eye surgery and previous eye diseases of 5.6\%. Other risk factors such as as dryness and trauma, facial palsy, previous viral infections, and dryness were counted as $2.8 \%, 2.8 \%, 3.7 \%$, and $3.7 \%$, respectively (Table 2). Agents responsible for the trauma were mainly vegetable matter in which it counts $36.4 \%$ of the total followed by blunt trauma in which it was $15.2 \%$, while chemical injury was only $6.1 \%$ of total trauma (Table 3,4 ). In other hand $42.4 \%$ of patients were unknown of the agents responsible for the trauma (Table 3,4).
Cornea laboratory diagnoses were positive in 77 patients (71.3\%). Of those individuals with positive cultures 46 (42.6\%) had pure bacterial infections, 7 (6.5\%) had pure viral infections, 6 (5.6\%) had pure fungal infections, 12 (11.1\%) had mixed bacteria and fungi, 1 $(0.9 \%)$ had mixed viral and fungi, and three $(2.8 \%)$ grew bacteria with parasitic infections (Table 5). The most common bacterial pathogen isolated was Staphylococcus aurous, representing $41.3 \%$ of all positive bacterial cultures, followed by Streptococcus viridians (6.3\%), and Staphylococcus epidermidis (6.3\%) (Table 6). The most common fungal pathogen isolated was Candida albicans, representing $41.2 \%$ of all positive fungal cultures, followed by Filamentous fungi (23.6\%) (Table 7).

Table 3: Occupations of 108 patients with corneal ulceration in Sana'a city.

\begin{tabular}{|c|c|c|}
\hline Occupations & Number & Percentage \\
\hline Agricultural worker/farmer & 12 & 11.1 \\
\hline Housewife/domestic & 14 & 13 \\
\hline Tradesman/profession/ official & 32 & 29.6 \\
\hline Student/child & 27 & 25 \\
\hline Unemployed/unknown & 23 & 21.3 \\
\hline Total & 108 & 100 \\
\hline
\end{tabular}

Table 4: Traumatic agents in $33(30.6 \%)$ of 108 patients with corneal ulceration.

\begin{tabular}{|c|c|c|}
\hline Traumatic Agent & Number of Cases & Percentage \\
\hline ‡Blunt trauma & 5 & 15.2 \\
\hline Vegetable matter* & 12 & 36.4 \\
\hline Chemical injury & 2 & 6.1 \\
\hline Unknown & 14 & 42.4 \\
\hline Total & 33 & 100 \\
\hline
\end{tabular}

Table 5: The prevalence rate of different microbial pathogens among suspected infective corneal infections among patients attending ophthalmic clinics in the main hospital of Sana'a city (etiological diagnosis of corneal ulceration in Sana'a city, Yemen).

\begin{tabular}{|c|c|c|c|}
\hline Final Laboratory Diagnosis & Number & Percentage & Significance \\
\hline Pure Bacterial infection & 46 & 42.6 & \multirow{3}{*}{$<0.05$} \\
\hline Pure Viral infection (HSV) & 7 & 6.5 & \\
\hline Pure Fungal infection & 6 & 5.6 & \\
\hline $\begin{array}{l}\text { Mixed bacterial and fungal } \\
\text { infection }\end{array}$ & 12 & 11.1 & \multirow{4}{*}{ NS } \\
\hline $\begin{array}{c}\text { Mixed bacterial and viral } \\
\text { infection }\end{array}$ & 2 & 1.9 & \\
\hline $\begin{array}{l}\text { Mixed viral and fungal } \\
\text { infection }\end{array}$ & 1 & 0.9 & \\
\hline $\begin{array}{l}\text { Mixed bacterial and parasitic } \\
\text { (Leishmania) infection }\end{array}$ & 3 & 2.8 & \\
\hline Etiological diagnosis & 77 & 71.3 & \multirow{2}{*}{$<0.05$} \\
\hline No microbiological growth & 31 & 28.7 & \\
\hline Total & 108 & 100 & \\
\hline
\end{tabular}

Table 6: Bacterial isolates from corneal ulcers in Sana'a city.

\begin{tabular}{|c|c|c|}
\hline Bacteria & Number of cases & Percentage \\
\hline Staph. aureus & 26 & 41.3 \\
\hline Acinetobacter spp & 2 & 3.2 \\
\hline Strep. viridance & 4 & 6.3 \\
\hline
\end{tabular}




\begin{tabular}{|c|c|c|}
\hline Nocardia spp & 1 & 1.6 \\
\hline Bacillus Subtitis & 1 & 1.6 \\
\hline Staph. epidermitis & 4 & 6.3 \\
\hline Proteus spp & 1 & 1.6 \\
\hline Haemophilus spp & 1 & 1.6 \\
\hline Pseudo. aerogenosa & 1 & 1.6 \\
\hline Strep. pnuemonia & 1 & 1.6 \\
\hline Alcaligens spp & 1 & 1.6 \\
\hline Haem. inflaunzea & 3 & 4.8 \\
\hline Psuedomonus spp & 1 & 1.6 \\
\hline Citrobacter spp & 1 & 1.6 \\
\hline P. stuteris and Staph. aureus & 2 & 3.2 \\
\hline Psuedo. aerogenosa and Alcaigens spp & 1 & 1.6 \\
\hline Cronybacter and Chaedonium spp & 1 & 1.6 \\
\hline Staph. aureus and Cronybacter spp & 1 & 1.6 \\
\hline Staph. aureus and B. cereus & 2 & 3.2 \\
\hline Staph. aureus and B. sulutis & 1 & 1.6 \\
\hline Staph. aureus and P. aerogenosa & 1 & 1.6 \\
\hline Staph. aureus and Pseudomonas spp & 1 & 1.6 \\
\hline Staph. aureus and Bacillus & 1 & 1.6 \\
\hline Micrococcus & 1 & 1.6 \\
\hline Staph. aureus and Shigella & 1 & 1.6 \\
\hline E. coli and positive gram bacterial & 1 & 1.6 \\
\hline Bacterial growth & 1 & 1.6 \\
\hline Total & 63 & 100 \\
\hline
\end{tabular}

Table 7: Fungal isolates from corneal ulcers in Sana'a Yemen.

\begin{tabular}{|c|c|c|}
\hline Fungi & Number of Cases & Percentage \\
\hline Aspergillus spp & 1 & 5.8 \\
\hline Candida spp & 7 & 41.2 \\
\hline Currularia spp & 1 & 5.8 \\
\hline Filamentous fungi & 4 & 23.6 \\
\hline Fusarium spp & 1 & 5.8 \\
\hline Microsporidium spp & 2 & 11.8 \\
\hline Sterial mycelus & 1 & 5.8 \\
\hline Total fungi & 17 & 15.7 \\
\hline Total number of ulcers & 108 & 100 \\
\hline
\end{tabular}

\section{Discussion}

In recent years, in Yemen, health care authorities as well as patients and family patients are increasingly concerned about the visual disability of corneal opacity. This general concern is well reflected in this study conducted, in our opinion (I and supervisors) this emerging issue should be discussed in the medical community in Yemen. To date, there have been no reports or studies conducted on the prevalence of various microbial pathogens among suspected infectious corneal infections among patients receiving eye clinics at the main hospital in Sana'a.

There is no doubt that the prevalence of visual impairment from corneal opacities varies from one geographical location to another, and in regions of the world where trachoma, onchocerciasis, leprosy and other infectious causes of eye diseases are endemic, blindness 
and chronic allergies are likely to undermine the corneas enough to allow the ulcer to develop. Di Bisceglie and Carmichael [19] and Dart, et al. [15], documented a similar list of predisposing factors in 71 ulcer patients in Africa.

Undoubtedly, the most common predisposing factor for corneal ulceration in Yemen is the history of corneal infection. Of 108, 29 patients $(26.9 \%)$ had a history of corneal trauma caused by a variety of organisms (Table 7). Thylefors [20] and Singh, et al. [11] noted that superficial corneal trauma in developing countries during agricultural work often leads to rapid progress in corneal ulceration and vision loss. Even though the amount of blindness in the world caused by trauma is not accurately known, Thylefors [20] estimates that up to $5 \%$ of all blindness or at least half a million individuals worldwide have lost their sight secondary to trauma. In Yemen vegetable matter (wood, hay, and grass) was the most common cause of superficial corneal trauma (36.4\%). Also 15.2\% of all patients with a history of trauma had blunt trauma with metal objects, broom sticks, ball and cloth as the traumatic object. This was followed by $6.1 \%$ with chemical injury (Tables 3,4 ). So, any programmed of prevention obviously must address these traumatic agents of corneal injury associated with corneal ulceration.

Microorganisms of 77 (71.3\%) were detected from 108 cultured corneas. This figure compares favorably with a study conducted in Ghana [9], where $57.3 \%$ of all cultures were positive, but did not approach the $80 \%$ isolation rate reported from Nepal by Upadhyay, et al. [3] or the recovery rate of $81.7 \%$ reported by Dunlop, et al. [8] in Bangladesh.

Even though multiple scrapings from the area of ulceration were performed and enriched media were used for inoculation as in the Nepal study [3], where there was an $80 \%$ recovery rate, the lower rate of isolation was attributed to the more widespread availability of topical medications in Yemen and their use in the majority of patients before evaluation. Approximately half (42.6\%) of all patients had bacterial corneal ulcers originally. If the 14 mixed infections (13\%) are also considered primarily bacterial for treatment purposes and are added to pure bacterial conditions, $58 \%$ of all positive ulcers of cultured ulcers cultivate bacterial pathogens. This figure is slightly higher than that approaching the rate of bacterial isolation in Ghana where Hagan, et al. [9] cultivated bacteria from $44.3 \%$ of 77 patients with positive cultures (Table 5).

Of the 63 bacterial isolates from 108 corneal ulcers, 41.3\% were Staphylococcus aureus (Table 6). This number is different from findings in Nepal [9], India [14] and Africa [7] where Streptococcus pneumoniae was the most frequently isolated bacterial pathogen. Unlike the industrialized world, where Pseudomonas spp and other opportunistic organisms are the most frequent causes of bacterial ulceration because of contact lenses and other risk factors, so in Yemen Staphylococcus aureus should always be considered as the most likely cause of bacterial corneal ulceration until proved otherwise. Even though Pseudomonas spp has been identified as a frequent cause of corneal ulceration in some developing countries, $[2,22]$ the importance of Staphylococcus aureus as a worldwide cause of corneal infections should not be underestimated because of the implicit need for adequate therapy with broad spectrum antibiotics for all ulcers until an etiological diagnosis has been made $[21,23,24]$. Other important causes of bacterial ulceration the current study included Pseudomonas spp (7.2\%), and Streptococcus viridans (6.3\%) staph epidermidis (6.3\%) and Haemophalus influenzae (4.8\%). One third of these bacteria were found in pure culture while the remainders were mixed evenly between bacterial and fungal infections. These bacteria are undoubtedly a primary cause of corneal ulceration as demonstrated in a report elsewhere $[15,20,25]$.

Of 17 fungal isolates cultured from 108 corneal ulcers 41.2\% were Candida albicans, followed by and Aspergillus spp (5.6\%), Fusarium spp (5.6\%), and the remaining organisms were a diverse mixture of unusual fungal pathogens including a large number of unidentified filamentous fungi (23.5\%). The fact that many of these organisms are insufficiently predictableand that in some cases it was difficult to determine genus was also reported by other investigators $[26,27]$. Different types of fungi can be easily described by a single spore culture. In this study any filamentous organisms that could not be positively identified by standard laboratory methods were listed as unidentified pigmented filamentous fungi. This pattern of fungal organisms, dominated by Candida albicans, is different from the spectrum of microbial keratitis reported from south Florida by Liesegang and Forster [26] and from Ghana by Hagan, et al. [9] in which Fusarium species accounting for $61 \%$ and $56 \%$ respectively. The climates in South Florida and Ghana are in many ways different from those of Sana'a, Yemen, which may explain the corresponding pattern of fungal organisms. However, our results resemble most of the world which, in most parts of the world, is Aspergillus spp or Candida albicans as a prevalent fungal pathogen responsible for fungal keratitis $[28,15,10]$. In the temperate climate of Nepal Upadhyay, et al (3) found that Aspergillus spp accounted for $47 \%$ of all fungal pathogens followed by Candida spp (13.2\%) and Fusarium spp (11.7\%). Obviously, fungal keratitis is an enormous public health problem in Yemen. The fact that $15.7 \%$ of all corneal ulcers seen at the Sana'a clinics was originally fungal and that the majority is caused by Candida albicans, one of the most virulent ocular pathogens ophthalmic pathogens, emphasizes the need for more effective diagnostic and treatment methods to reduce the burden of avoidable blindness.

\section{Conclusion}

The present study has provided useful information about the prevalence of bacterial and fungal corneal ulceration in eye clinics in Sana'a city-Yemen, the prevalence of keratitis was more common among male, middle age persons. Staphylococcus aureus was the most common bacterial isolate, fungal keratitis infection was less common than bacterial infections with predominant of Candida albicans. The time of symptoms with corneal ulcer before evaluation at hospital in Yemen is longer than that reported elsewhere and great risks of Keratitis were found to be associated with history of trauma, eye surgery, facial palsy and systemic diseases. 


\section{Recommendations}

This study was developed primarily to determine the specific pathogens responsible for corneal ulceration Yemen. An attempt was also made to identify the epidemiological characteristics of the population at risk for corneal ulceration as well as those factors which predispose to the development of an ulcer. We feel that comprehensive surveys such as this are necessary to assess the specific epidemiological characteristics of corneal ulceration which are unique for each region and population. This knowledge is essential, firstly, to define the magnitude of the problem in terms of health care costs, human costs, and the economic burden of blindness and, secondly, to design an efficient public health programmed for the rapid referral, diagnosis, treatment, and ultimately the prevention of corneal ulceration in the population at risk. This approach has important public health implications for the treatment and prevention of corneal ulceration in the developing world.

Future research should be directed at assessing the rate of infectious keratitis with large sample size and this study is only the first step in addressing this goal. Also, further studies must be done to determine all the etiological agents that cause keratitis other than microorganisms isolated for the all governorates of the country and the periodical testing of more recent antibiotics for accurate susceptibility.

\section{Ethical Approval}

The study protocol was approved by the Ethical Committee of the Faculty of Medicine at Faculty of Medicine, Sana'a University, Yemen (MECA NO: 2016/292).

\section{Authors' Contribution}

The manuscript was carried out, written, and approved in collaboration with all authors.

\section{Acknowledgement}

The clinical samples culturing, and microbiology diagnosis were done at National Center of Public Health laboratories Sana'a (NCPHL).

\section{Conflict of Interest}

There are no conflicts of interest.

\section{References}

1. WHO (2019) Priority eye diseases - Blindness and vision impairment prevention? World Health Organization, USA.

2. Robaie Dana, Watson Stephanie Louise (2014) Corneal blindness: A global problem. Clin Exp Ophthalmol 42(3): 213-214.

3. Upadhyay MP, Karmacharya PC, Koirala S, Tuladhar N, Bryan LE, et al. (1991) Epidemiologic characteristics, predisposing factors, and etiologic diagnosis of corneal ulceration in Nepal. Am J Ophthalmol 111(1): 92-99.

4. Ormerod LD (1987) Causation and management of microbial keratitis in subtropical Africa. Ophthalmology 94(12): 1662-1668.

5. Katz NN, Wadud SA, Ayazuddin M (1983) Corneal ulcer disease in Bangladesh. Ann Ophthalmol 15(3): 834-837.

6. Mahajan VM (1985) Ulcerative keratitis: an analysis of laboratory data in 674 cases. J Ocul Ther Surg 4: 138-141.
7. Carmichael TR, Wolpert M, Koornhob HJ (1985) Corneal ulceration at an urban African hospital. Br J Ophthalmol 69(12): 920-926.

8. Dunlop AA, Wright ED, Howlader SA, Nazrul I, Husain R, et al. (1994) Suppurative corneal ulceration in Bangladesh: a study of 142 cases examining the microbiological diagnosis, clinical and epidemiological features of bacterial and fungal keratitis. Aust N Z J Ophthalmol 22(2): 105-110.

9. Hagan M, Wright E, Newman M, Dolin P, Johnson G (1995) Causes of suppurative keratitis in Ghana. Br J Ophthalmol 79(11): 1024-1028.

10. Pascolini D, Mariotti SP (2011) Global estimates of visual impairment: 2010. Br J Ophthalmol 96(5): 614-618.

11. Singh N, Shiva Shankar Eeda, Bala Krishna Gudapati, Srinivasa Reddy, Pushkar Kanade, et al. (2014) Prevalence and Causes of Blindness and Visual Impairment and Their Associated Risk Factors, in Three Tribal Areas of Andhra Pradesh, India. PLoS One 9(7): e100644.

12. Rapoza PA, West SK, Katala SJ, Taylor HR (1991) Prevalence and causes of vision loss in central Tanzania. Int Ophthalmol 15(2): 123-129.

13. Gonzales CA, Srinivasan M, Whitcher JP, Smolin G (1996) Incidence of corneal ulceration in Madurai District, South India. Ophthalmic Epidemiol 3(3): 159-166.

14. Srinivasan M, Christine A Gonzales, Celine George, Vicky Cevallos, Jeena M, et al. (1997) Epidemiology and aetiological diagnosis of corneal ulceration in Madurai, south India. Br J Ophthalmol 81(11): 965-971.

15. Dart JK, Radford CF, Minassian D, Verma S, Stapleton F (2008) Risk factors for microbial keratitis with contemporary contact lenses: a casecontrol study. Ophthalmology 115(10): 1647-1654.

16. Cho P, Cheung SW (2012) Retardation of Myopia in Orthokeratology (ROMIO) study: a 2-year randomized clinical trial. Invest Ophthalmol Vis Sci 53(11): 7077-7085.

17. Yorston D, Foster A (1994) Traditional eye medicines and corneal ulceration in Tanzania. J Trop Med Hyg 97(4): 211-214.

18. Courtright P, Lewallen S, Kanjaloti S, Dighton D (1994) Traditional eye medicine use among patients with corneal disease in rural Malawi. Br J Ophthalmol 78(11): 810-812.

19. Di Bisceglie AM, Carmichael TR (1987) Factors predisposing to central corneal ulceration in a developing population. S Afr Med J 71(12): 769770 .

20. Thylefors B (1992) Epidemiological patterns of ocular trauma. Aust NZ J Ophthalmol 20(2): 95-98.

21. Freidlin J, Acharya N, Lietman TM, Cevallos V, Whitcher JP, et al. (2007) Spectrum of eye disease caused by methicillin-resistant Staphylococcus aureus. Am J Ophthalmol 144(2): 313-315.

22. Chih Chun Chuang, Ching Hsi Hsiao, Hsin Yuan Tan, David Hui-Kang Ma et al. (2012) Staphylococcus aureus Ocular Infection: MethicillinResistance, Clinical Features, and Antibiotic Susceptibilities. PLoS One 8(8): e42437.

23. Shanmuganathan VA, Armstrong M, Buller A, Tullo AB (2005) External ocular infections due to methicillin-resistant Staphylococcus aureus (MRSA). Eye (Lond) 19(3): 284-291.

24. Blomquist PH (2006) Methicillin-resistant Staphylococcus aureus infections of the eye and orbit (an American Ophthalmological Society thesis). Trans Am Ophthalmol Soc 104: 322-345.

25. Rubinfeld R, Cohen E, Arentsen J, Laibson P (1989) Diphtheroids as ocular pathogens. Am J Ophthalmol 108: 251-254.

26. Liesegang TJ, Forster RK (1980) Spectrum of microbial keratitis in south Florida. Am J Ophthalmol 90(1): 38-47.

27. Sharma S, Srinivasan M, George C (1993) The current status of Fusarium species in mycotic keratitis in south India. Indian J Med Microbiol 11: 140-147.

28. Jones BR (1975) Principles in the management of oculomycosis. XXXI Edward Jackson Memorial Lecture. Am J Ophthalmol 79(5): 719-751. 